ISSN 2078-5615. Вісник Львівського університету. Серія хімічна. 2018. Випуск 59. Ч. 2. С. 450-459 Visnyk of the Lviv University. Series Chemistry. 2018. Issue 59. Pt. 2. P. 450-459

УДК 541.18.05/.052 : 544.77.023.55 : 546.57

КОНТРОЛЬОВАНИЙ СИНТЕЗ НАНОПОРОШКІВ СРІБЛА

\author{
Л. Базиляк \\ Відділення фізико-хімії горючих копалин \\ Інституту фізико-органічної хімії і вуглехімії ім. Л. М. Литвиненка НАН Украӥни, \\ вул. Наукова, За, Львів, 79060 Україна \\ e-mail:Bazyljak.L.I@nas.gov.ua
}

\begin{abstract}
Методом спектроскопії в УФ-видимому діапазоні досліджено постадійне відновлення іонів $\mathrm{Ag}^{+}$гідразином у присутності срібних центрів нуклеації без використання стабілізаторів. На кожному етапі процесу за максимумами смуг поверхневого плазмонного резонансу визначено значення середнього діаметру отримуваних наночастинок срібла. 3'ясовано, що такі значення добре узгоджуються 3 теоретично очікуваними, що $\epsilon$ свідченням високої прогнозованості досліджуваного способу отримання нанопорошків срібла, вихід яких у досліджуваних умовах перевищує 85 \%. 3 використанням UV/vis спектроскопії і сканівної електронної мікроскопії визначено, що отримані нанопорошки срібла добре редиспергуються у воді, причому розраховані з використанням розподілу Гауса і логнормального розподілу середні діаметри наночастинок срібла у вихідному золі та після редиспергування осадженого і висушеного нанопорошку срібла у воді $є$ близькими і $є$ в межах похибки експерименту.
\end{abstract}

Ключові слова: нанопорошки, срібло, центри кристалізації, гетерогенна нуклеація, поверхневий плазмонний резонанс.

DOI: https://doi.org/10.30970/vch.5902.450

Упродовж останніх років простежується експоненційний ріст кількості публікацій в області фундаментальних та прикладних наук, пов'язаних із синтезом наночастинок металів, вивченням їх властивостей та практичним застосуванням [1]. Відкрилися нові перспективні можливості використання металевих наночастинок $\mathrm{i}$ наносистем у багатьох галузях науки і техніки, оскільки вони володіють низкою унікальних властивостей, зокрема, оптичними [2-5], каталітичними [6-9], антимікробними [10-13], магнітними [14-16] та іншими, що робить ї особливо перспективними матеріалами для створення нових об'єктів у медицині [17], розробки елементів мікроелектронних та оптичних пристроїв в мікроелектроніці [18], отримання ефективних й селективних каталізаторів [6-9], розробки селективних датчиків у сенсорному аналізі [19] і т. д. Зацікавленість дослідників до нанорозмірних частинок металів буде 3 кожним роком усе більше зростати, оскільки наночастинки і кластери металів є важливим станом конденсованої фази (тобто займають проміжне положення між атомно-молекулярним та конденсованим станами речовини). Власне 3 цього факту і випливають їх незвичні властивості. Оскільки сьогодні створення наноматеріалів стало об’єктом нового напряму в науці - нанохімії (термін “нанохімія” не є “канонізованим”, однак досить багато дослідників уважають iii самостійним науковим напрямом [1]); розуміння особливостей впливу розміру чи

(с) Базиляк Л., 2018 
Л. Базиляк

ISSN 2078-5615. Вісник Львівського університету. Серія хімічна. 2018. Випуск 59. Ч. 2

кількості атомів у частинці на фізико-хімічні властивості та реакційну здатність $є$ одним 3 іiі фундаментальних завдань. Отже, в процесі синтезу морфометричні та фізико-хімічні характеристики наночастинок металів суттєво залежать від значної кількості параметрів, які іноді дуже складно контролювати. Крім того, такі параметри можуть змінюватися під час самого процесу синтезу, а тому необхідність керованого (чи контрольованого) синтезу наночастинок металів із заданими властивостями, які зумовлені сильним впливом розмірів, форм і структур металічних наночастинок та їх агрегатів на властивості утворюваних ними систем, $є$ актуальним завданням сучасної колоїдної та нанохімії. Багато нюансів технологій отримання наночастинок металів мають емпіричний характер, i лише окремі процеси можуть бути строго алгоритмізованими, що не дає змоги прогнозовано коректувати методики синтезу для отримання колоїдних частинок заданого розміру. Отже, розробка нових дешевих i відтворюваних способів синтезу та модифікації металевих наночастинок $\epsilon$ актуальним завданням нанохімії.

Способами керування розмірами наночастинок металів, які застосовують у науковій практиці, є використання полімерних матриць, які дають змогу керувати розмірами нанокластерів, фізичні методи (обробка ультразвуком, опромінення рентгенівським випромінюванням та використання струмів високої частоти) тощо. Контролювати розміри наночастинок металів можна також варіацією природи відновника. Так, наприклад, використання боргідриду натрію у відновленні іонів $\mathrm{Ag}^{+}$ дає змогу отримувати наночастинки срібла 3 вузьким розподілом за розмірами в межах 2-8 нм, тоді як відновлюючи за допомогою гідразину, можна отримувати наночастинки срібла з розміром 15-30 нм [2]. Серед усіх досліджуваних синтезів наночастинок металів найбільшу кількість робіт присвячено синтезу власне наночастинок срібла у водному середовищі, оскільки саме такий процес є відносно простим і доступним у плані його експериментального оформлення, а тому таку систему можна вважати модельною у дослідженні процесів контрольованого синтезу нанопорошків. Причому одним з найбільш перспективних способів контрольованого синтезу наночастинок металів, зокрема наночастинок срібла, $\epsilon$ їх синтез у гетерогенних системах, а саме в присутності введених у систему попередньо синтезованих центрів нуклеації [20]. Відомі способи синтезу наночастинок срібла із зародків срібла 10 нм 3 подальшим їх ростом до 150 нм [21], нанокубів та нанооктаедрів срібла з розмірами 20-70 нм [22]. Водночас, незважаючи на досить грунтовне висвітлення таких методів синтезу наночастинок срібла, кількість публікацій, які присвячені розробці нових способів контрольованого синтезу наночастинок срібла зростає, що свідчить про актуальність такої проблеми. Зокрема, цікавою й актуальною $є$ проблема отримання сухих срібних нанопорошків, які можуть задовільно редиспергуватися у гідрофільному та/або гідрофобному середовищах, оскільки для окремих прикладних задач, наприклад, для приготування електропровідних композицій [23], каталізу рідиннофазового окиснення органічних субстратів [24] тощо, використання отримуваних колоїдних розчинів срібла $\epsilon$ недоцільним. Тому мета цієї праці - дослідити процес контрольованого синтезу нанопорошків срібла, які добре редиспергуються у воді.

Нанопорошки срібла синтезували постадійним відновленням нітрату срібла $\left[\left(\mathrm{AgNO}_{3}\right.\right.$ марка “ $x$. ч.”, замовлений за каталогом фірми “Сфера Сім" (Україна) 3 масовою часткою основної речовини 99 \%)] гідразином [ $\left(\mathrm{N}_{2} \mathrm{H}_{4} \times \mathrm{H}_{2} \mathrm{O}\right.$ марки “ч.д.а.", замовлений за каталогом фірми “Сфера Сім” (Україна) з масовою часткою основної 
речовини $\geq 99 \%$ ] в термостатованому скляному реакторі, обладнаному магнітною мішалкою при $25^{\circ} \mathrm{C}$ в присутності попередньо синтезованих [20, 25] срібних зародків кристалізації з розміром $15 \pm 4$ нм за наступною методикою: до 50 мл золю центрів кристалізації з частинковою концентрацією наночастинок срібла $\mathrm{N}_{\mathrm{Ag}}=2,4 \times 10^{15}$ л $^{-1}$ за постійного перемішуванні додавали 0,2 мл гідразину, після чого до реакційної суміші поступово (порційно по 0,2 мл) додавали 2,4 мл розчину нітрату срібла $(0,4$ моль/л). Отриманий осад відділяли центрифугуванням при $3000 \mathrm{xв}^{-1}$ упродовж 15 хв 3 використанням центрифуги К-24 D (“MLW Zentrifugenbau Engelsdorf”) (Німеччина), промивали надлишком дистильованої води і висушували на повітрі при $90{ }^{\circ} \mathrm{C}$ до постійної маси. Отриманий продукт - порошок чорного кольору; вихід цільового продукту становив $85 \%$. Оскільки в реакційній системі наявний багатократний надлишок гідразину відносно $\mathrm{Ag}^{+}$, а також, зважаючи на відсутність забарвлення маточного розчину після центрифугування, можна припустити, що втрата цільового продукту відбулась на стадіях його очистки.

Перебіг реакції контролювали за зміною спектрів поглинання срібних золів на різних стадіях процесу (рис. 1) з використанням однопроменевого спектрофотометра УФ-видимого діапазону Uv-mini-1240 (Shimadzu Corp., Kyoto, Japan) (досліджуваний діапазон 300-1 100 нм 3 використанням кварцової кювети 3 довжиною оптичного шляху $l=1,0 \mathrm{~cm})$.

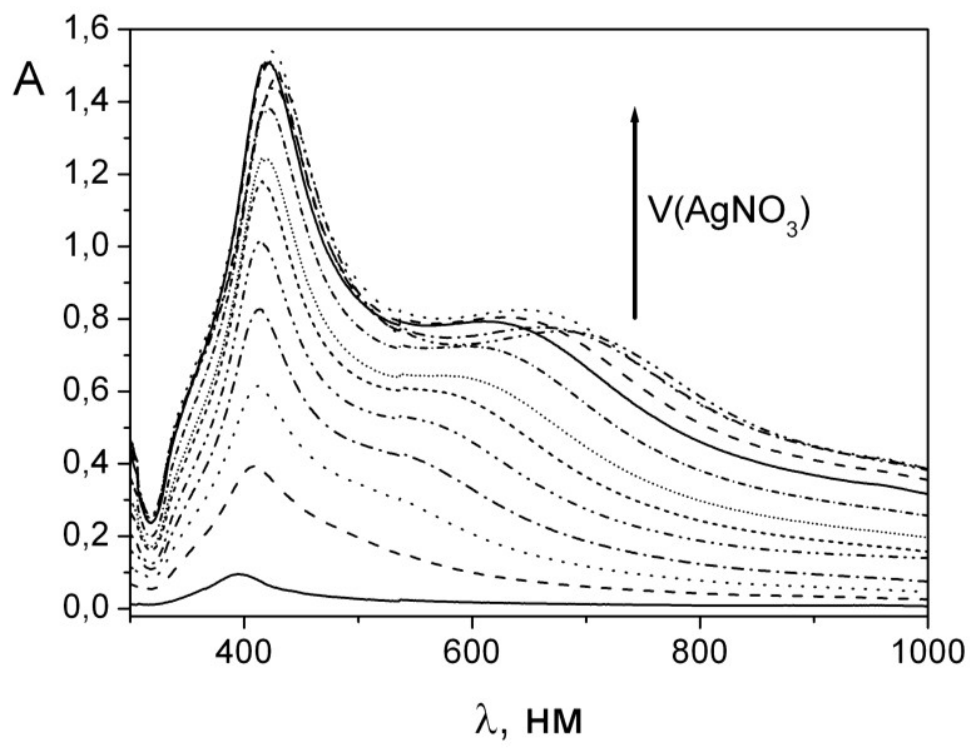

Рис. 1. Зміна електронних спектрів поглинання срібних золів за порційного (по 0,2 мл) додавання розчину $\mathrm{AgNO}_{3}$ від 0 до 2,4 мл

Fig.1 Change of the electronic absorption spectra of silver sols at portional $(0.2 \mathrm{ml})$ addition of solution of $\mathrm{AgNO}_{3}$ from 0 to $2.4 \mathrm{ml}$

За електронними спектрами поглинання поверхневого плазмонного резонансу (ППР) (значеннями максимумів $\left(\lambda_{\max }\right)$ смуг поглинання та їх шириною $(\Delta \lambda)$ на половині висоти) визначено значення середнього діаметра [26] отримуваних наночастинок срібла (табл. 1). Оскільки відомо [25], що швидкість автокаталітичного 
росту наночастинок срібла є на 5-6 порядків вищою, ніж швидкість їх гомогенного зародження, то можна припустити, що під час перебігу процесу в реакційній суміші переважає процес зростання срібних зародків i, в подальшому, наночастинок, а гомогенна нуклеація срібла суттєво не впливає як на перебіг процесу, так і на розмір отримуваних частинок. На основі такого твердження, а також припускаючи, що конверсія за $\mathrm{Ag}^{+}$на усіх стадіях перебігу процесу є близькою до $100 \%$ (що є цілком імовірним, оскільки в системі міститься більш ніж п'ятнадцятикратний надлишок гідразину відносно $\mathrm{Ag}^{+}$), запропоновано формулу (1) для розрахунку очікуваного діаметра отримуваних наночастинок срібла.

$$
\mathrm{m}(\mathrm{Ag})=\mathrm{m}_{0}+\Delta \mathrm{V} \cdot \mathrm{C}=\frac{1}{6} \pi \cdot \rho_{\mathrm{Ag}} \cdot \mathrm{d}^{3} \cdot \mathrm{N}_{\mathrm{Ag}} \Rightarrow \mathrm{d}=\left[\frac{6\left(\mathrm{~m}_{0}+\Delta \mathrm{V} \cdot \mathrm{C}\right)}{\pi \cdot \rho_{\mathrm{Ag}} \cdot \mathrm{N}_{\mathrm{Ag}}}\right]^{\frac{1}{3}}
$$

де $\mathrm{m}(\mathrm{Ag})$ - загальна маса срібла в реакційній суміші; $\mathrm{m}_{0}$ - маса срібних центрів нуклеації; $\Delta \mathrm{V}, \mathrm{C}$ - об’єм і концентрація доданого розчину срібла, відповідно; $\rho_{\mathrm{Ag}}-$ густина срібла.

Визначені за параметрами смуг ППР і очікувані значення середнього діаметру (d) наночастинок срібла за порційного додавання розчину $\mathrm{AgNO}_{3}$

Table 1

The defined by the parameters of SPR bands and expected values of the average diameter (d) of silver nanoparticles at the portional adding of solution of $\mathrm{AgNO}_{3}$

\begin{tabular}{|c|c|c|c|c|}
\hline \multirow{2}{*}{$\begin{array}{c}\text { Об'єм доданого } \\
\text { AgNO }_{3, \text { мл }}\end{array}$} & \multirow{2}{*}{$\begin{array}{c}\lambda_{\max }, \\
\text { нм }\end{array}$} & \multirow{2}{*}{$\begin{array}{c}\Delta \lambda, \\
\text { нм }\end{array}$} & $\begin{array}{c}\text { Вередній діаметр наночастинок срібла, нм } \\
\text { (за методиконо }[26])\end{array}$ & $\begin{array}{c}\text { Очікуваний d, нм } \\
\text { (за рівнянням 1) }\end{array}$ \\
\hline 0 & 395 & 70 & $15 \pm 4$ & - \\
0,2 & 408 & 115 & $30 \pm 14$ & 26 \\
0,4 & 411 & 124 & $33 \pm 17$ & 31 \\
0,6 & 413 & 118 & $35 \pm 17$ & 35 \\
0,8 & 415 & 114 & $37 \pm 17$ & 38 \\
1,0 & 417 & 115 & $39 \pm 18$ & 41 \\
1,2 & 420 & 117 & $42 \pm 20$ & 44 \\
1,4 & 422 & 117 & $44 \pm 21$ & 48 \\
1,6 & 422 & 116 & $44 \pm 21$ & 49 \\
1,8 & 424 & 119 & $46 \pm 22$ & 51 \\
2,0 & 425 & 123 & $47 \pm 24$ & 53 \\
2,2 & 427 & 122 & $49 \pm 25$ & 54 \\
2,4 & 429 & 125 & $51 \pm 26$ & \\
\hline
\end{tabular}

Як бачимо $з$ наведених в табл. 1 даних, визначені за максимумом ППР i розраховані за рівнянням (1) значення середнього діаметру утворюваних наночастинок срібла практично збігаються, що підтверджує припущення про гетерогенний механізм росту наночастинок і свідчить про високу прогнозованість досліджуваного способу отримання нанопорошків срібла.

3 метою перевірки можливості утворення водних золів срібла 3 отриманих нанопорошків (редиспергованості нанопорошків) наважку порошку диспергували у воді $з$ використанням ультразвукової ванни “Кристалл-2М” впродовж 15 хв, після чого отриманий золь досліджували методами спектроскопії в УФ-видимому діапазоні та електронної сканівної мікроскопії (електронний мікроскоп EVO-40XVP (Carl Zeiss)). 
Спектри ППР золів, отриманих безпосередньо після синтезу і редиспергування нанопорошку у воді, а також CЕМ-зображення наночастинок срібла наведено на рис. 2 і 3, відповідно.

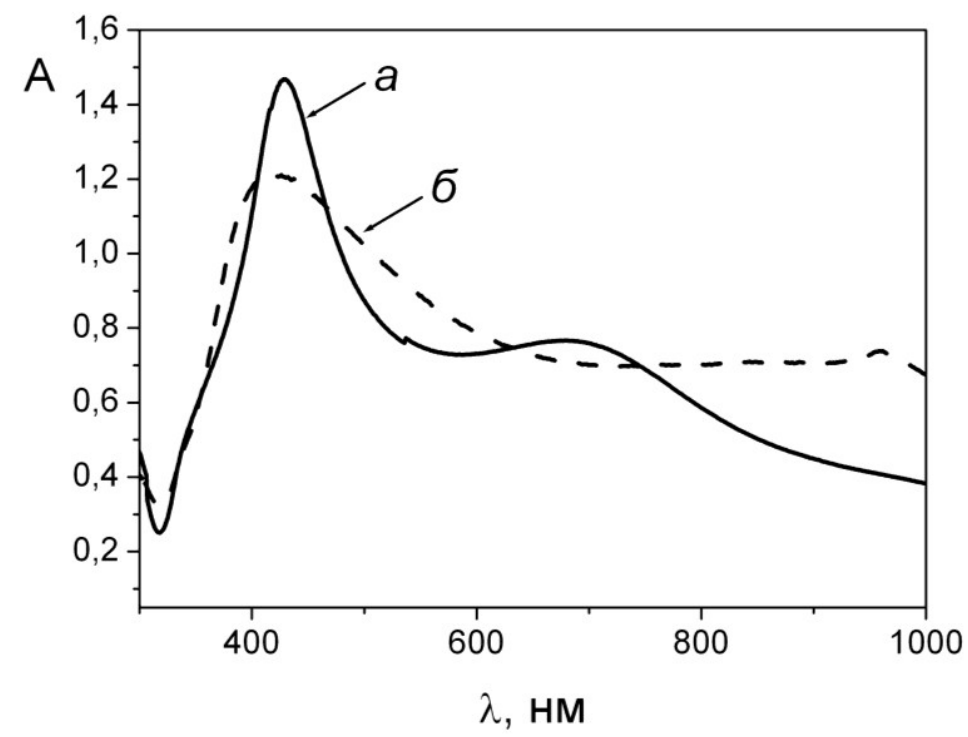

Рис. 2. Спектри ППР золів, отриманих безпосередньо після синтезу $(a)$ і редиспергування нанопорошку срібла у воді (б)

Fig. 2 SPR spectra of sols obtained immediately after synthesis $(a)$ and redispersing of silver nanopowders in water $(\sigma)$

Як бачимо з наведених на рис. 2 спектрів, максимуми поглинання ППР для золів срібла, отриманих безпосередньо після синтезу і редиспергування нанопорошку у воді, $\epsilon$ близькими, а більша ширина смуги ППР золю редиспергованого нанопорошку свідчить про дещо більшу полідисперсність наночастинок срібла. Про це також свідчать наведені на рис. $3(a$, б) СЕМ-зображення наночастинок срібла. Так, якщо у випадку вихідного золю практично всі наночастинки срібла $\epsilon$ кулеподібними, а їх діаметр не перевищує 90 нм, то на СЕМ-зображенні редиспергованих частинок трапляються агломерати неправильної форми з розміром 120 нм. Водночас, розраховані за рис. 3 значення середнього діаметра наночастинок срібла відрізняються незначно, а відмінною $є$ лише розрахована 3 використанням розподілу Гауса (рис. 3, в) та логнормального розподілу (рис. 3, г) з рівнем довіри 0,95 полідисперсність частинок, яка становить \pm 56 нм у випадку редиспергованих порошків срібла і \pm 30 нм - у випадку свіжоприготовлених наночастинок срібла. Однак таке зростання полідисперсності частинок після диспергування нанопорошків срібла у воді можна вважати незначним, а самі порошки - придатними для використання у подальших дослідженнях, зокрема для перевірки їх каталітичної активності [24], як наповнювачів в електропровідних полімерних композиціях тощо. 


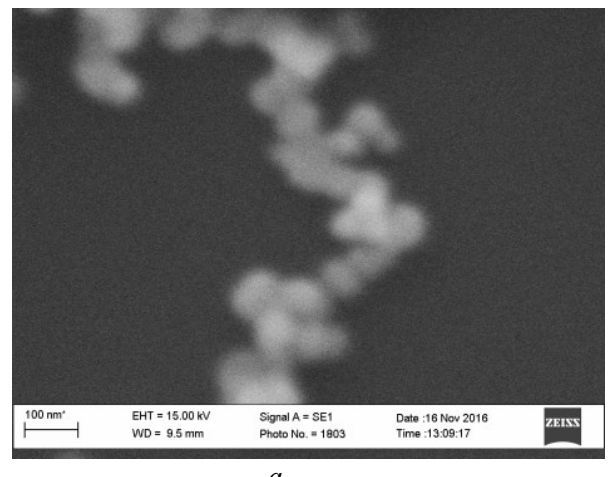

$a$

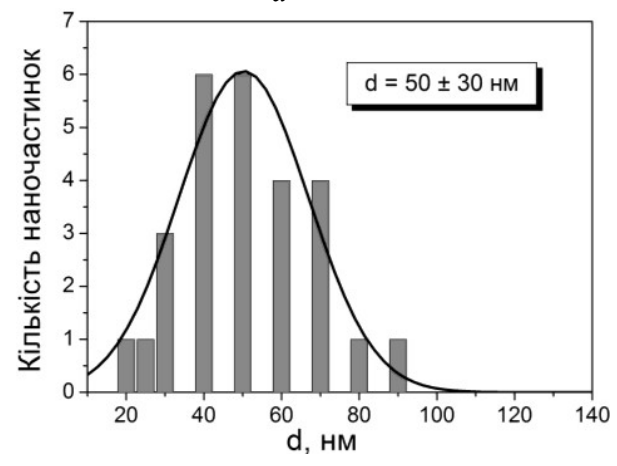

b
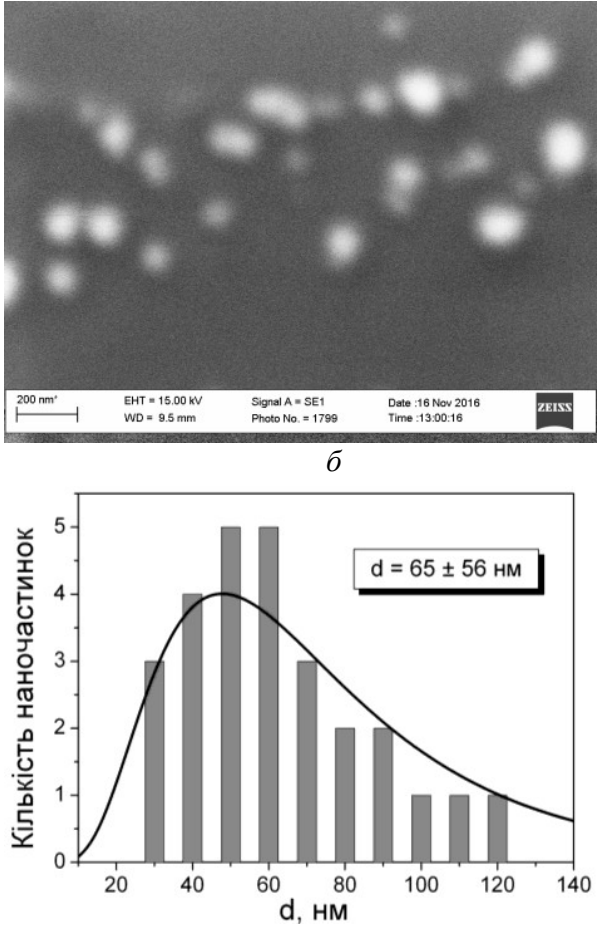

Рис. 3. СЕМ-зображення наночастинок срібла, отримані безпосередньо після синтезу $(a) \mathrm{i}$ редиспергування нанопорошку срібла у воді (б) та їх розподіл за розміром $(b, 2)$

Fig. 3 SEM-images of silver nanoparticles obtained immediately after synthesis $(a)$ and redistribution of silver nanopowders in water $(\sigma)$ as well as their sizes distributioni $(6,2)$

Варто зазначити, що за непорційного (одноразового) додавання до реакційної суміші (золь срібних зародків + гідразин) 2,4 мл 0,4 M розчину $\mathrm{AgNO}_{3}$ утворюється полідисперсний порошок з розміром частинок 0,1-2 мкм (рис. 4).

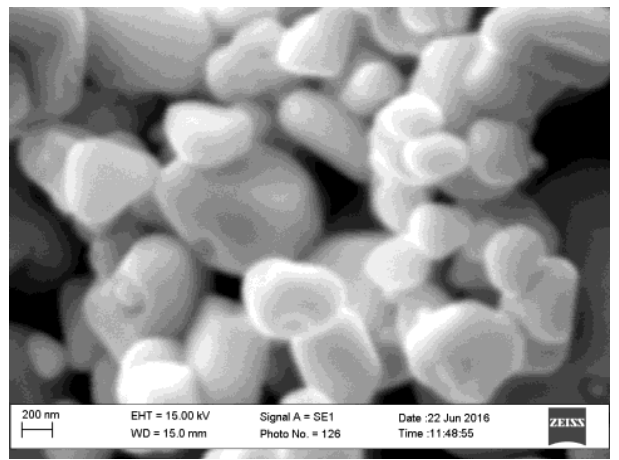

Рис. 4. СЕМ-зображення частинок срібла, отриманих за одноразового додавання 2,4 мл розчину $\mathrm{AgNO}_{3}$ до розчину центрів нуклеації з гідразином

Fig. 4. SEM-image of silver particles obtained by adding of $2.4 \mathrm{ml}$ of $\mathrm{AgNO}_{3}$ solution to a solution of nucleation centers and hydrazine 
Імовірно, що великі розмір і полідисперсність частинок срібла, отримані за одноразового додавання 2,4 мл $0,4 \mathrm{M}$ розчину $\mathrm{AgNO}_{3}$ до золю зародків, спричинені неконтрольованими процесами гомогенної нуклеації, автокаталітичного росту, агрегації наночастинок срібла і вторинного росту утворюваних агрегатів [27] через надзвичайно високі концентрації реагентів - 0,02 моль/л $\mathrm{AgNO}_{3}$ і 0,08 моль/л $\mathrm{N}_{2} \mathrm{H}_{4}$. Однак для підтвердження такого припущення необхідним $є$ проведення додаткових досліджень.

Отже, ступеневе відновлення іонів $\mathrm{Ag}^{+}$гідразином у присутності срібних центрів нуклеації $є$ перспективним, простим і недорогим методом для отримання редиспергабельних нанопорошків срібла з наперед прогнозованим розміром частинок навіть за відсутності поверхнево-активних речовин.

Подані у статті результати досліджень отримано під час виконання бюджетної теми П1/17 "Розробка кінетично контрольованих методів синтезу біметалевих наночастинок $\mathrm{Ni}-\mathrm{Me}(\mathrm{Me}=\mathrm{Ag}, \mathrm{Cu})$ як наповнювачів для електропровідних композицій” (0117U004289), яку включено в Національну науково-технічну програму "Прикладні наукові та науково-технічні розробки, виконання робіт за державними цільовими програмами, технічне забезпечення НАН України”, а також за часткової фінансової підтримки Державного фонду фундаментальних досліджень (конкурсний проект ДФФД № 20440; Договір № Ф71/32-2017).

1. Melichov I. V. Trends in the development of nanochemistry // Rus. Chem. J. 2002. Vol. 46. No. 5. P. 7-14 (in Russian).

2. Krutyakov Yu. A., Kudrinskiy A. A., Olenin A. Yu., Lisichkin G. V. Synthesis and properties of silver nanoparticles: advances and prospects // Russ. Chem. Rev. 2008. Vol. 77. P. 233-233. DOI: https://doi.org/10.1070/RC2008v077n 03ABEH003751

3. Kelly K. L., Coronado E., Zhao L. L., Schatz G. C. The optical properties of metal nanoparticles: the influence of size, shape, and dielectric environment // J. Phys. Chem. B. 2003. Vol. 107. No. 3. P. 668-677. DOI: https://doi.org/10.1021/jp026731y

4. Sosa I. O., Noguez C., Barrera R. G. Optical properties of metal nanoparticles with arbitrary shapes // J. Phys. Chem. B. 2003. Vol. 107. No. 26. P. 6269-6275. DOI: https://doi.org/10.1021/jp0274076

5. Rechberger W., Hohenau A., Leitner A., Krenn J. R., Lamprecht B., Aussenegg F. R. Optical properties of two interacting gold nanoparticles // Optics Comm. 2003. Vol. 220. No. 1. P. 137-141. DOI: https://doi.org/10.1016/S0030-4018(03)01357-9

6. Zeng J., Zhang Q., Chen J., Xia Y. A comparison study of the catalytic properties of $\mathrm{Au}-$ based nanocages, nanoboxes, and nanoparticles // Nano letters. 2009. Vol. 10. No. 1. P. 30-35. DOI: https://doi.org/10.1021/n1903062e

7. Wei Y., Chen S., Kowalczyk B., Huda S., Gray T. P., Grzybowski B. A. Synthesis of stable, low-dispersity copper nanoparticles and nanorods and their antifungal and catalytic properties // J. Phys. Chem. C. 2010. Vol. 114. No. 37. P. 15612-15616. DOI: https://doi.org/10.1021/jp1055683

8. Mei Y., Lu Y., Polzer F., Ballauff M., Drechsler M. Catalytic activity of palladium nanoparticles encapsulated in spherical polyelectrolyte brushes and core-shell microgels // Chem. Mater. 2007. Vol. 19. No. 5. P. 1062-1069. DOI: https://doi.org/10.1021/cm062554s 
9. Jin P., Chen Q., Hao L., Tian R., Zhang L., Wang L. Synthesis and catalytic properties of nickel-silica composite hollow nanospheres // J. Phys. Chem. B. 2004. Vol. 108. No. 20. P. 6311-6314. DOI: https://doi.org/10.1021/jp049754g

10. Zawrah M. F., El-Moez S. A., Center D. Antimicrobial activities of gold nanoparticles against major foodborne pathogens // Life Sci. J. 2011. Vol. 8. No. 4. P. 37-44.

11. Sharma V. K., Yngard R. A., Lin Y. Silver nanoparticles: green synthesis and their antimicrobial activities // Advances in colloid and interface science. 2009. Vol. 145. No. 1. P. 83-96. DOI: https://doi.org/10.1016/j.cis.2008.09.002

12. Ruparelia J. P., Chatterjee A. K., Duttagupta S. P., Mukherji S. Strain specificity in antimicrobial activity of silver and copper nanoparticles // Acta biomaterialia. 2008. Vol. 4. No. 3. P. 707-716. DOI: https://doi.org/10.1016/j.actbio.2007.11.006

13. Ramyadevi J., Jeyasubramanian K., Marikani A., Rajakumar G., Rahuman A. A. Synthesis and antimicrobial activity of copper nanoparticles // Materials Letters. 2012. Vol. 71. P. 114-116. DOI: https://doi.org/10.1016/j.matlet.2011.12.055

14. $W u S$. H., Chen D. H. Synthesis and characterization of nickel nanoparticles by hydrazine reduction in ethylene glycol // J. Colloid Interface Sci. 2003. Vol. 259. No. 2. P. 282-286. DOI: https://doi.org/10.1016/S0021-9797(02)00135-2

15. Chen Y., Peng D. L., Lin D., Luo X. Preparation and magnetic properties of nickel nanoparticles via the thermal decomposition of nickel organometallic precursor in alkylamines // Nanotechnology. 2007. Vol. 18. No. 50. P. 505703. DOI: https://doi.org/10.1088/0957-4484/18/50/505703

16. Couto G. G., Klein J. J., Schreiner W. H. et al. Nickel nanoparticles obtained by a modified polyol process: synthesis, characterization, and magnetic properties // Journal of colloid and Interface science. 2007. Vol. 311. No. 2. P. 461-468. DOI: https://doi.org/10.1016/j.jcis.2007.03.045

17. Huang X., Jain P. K., El-Sayed I. H., El-Sayed M. A. Gold nanoparticles: interesting optical properties and recent applications in cancer diagnostics and therapy // Nanomedicine. 2007. Vol. 2. No. 5. P. 681-693. DOI: https://doi.org/10.2217/17435889.2.5.681

18. Verrelli E., Tsoukalas D., Giannakopoulos K., Kouvatsos D., Normand P., Ioannou D. $E$. Nickel nanoparticle deposition at room temperature for memory applications // Microelectron. Eng. 2007. Vol. 84. P. 1994-1997. DOI: https://doi.org/10.1016/j.mee.2007.04.078

19. Wang $S$. F., Xie F., Hu R. F. Carbon-coated nickel magnetic nanoparticles modified electrodes as a sensor for determination of acetaminophen // Sensors and Actuators B. 2007. Vol. 123. No. 1. P. 495-500. DOI: https://doi.org/10.1016/10.1016/j.snb.2006.09.031

20. Kytsya A., Bazylyak L. Kinetics of silver nanoparticles formation in the presence of nucleation centers // Coll. scientific works of NTSh. Chemistry and biochemistry. 2017. Vol. XLVIII. P. 48-63. (in Ukrainian)

21. Malynych S. Z. Synthesis and optical propertties of superdispersed silver aqueous suspensions // Journal of Physical Studies. 2009. Vol. 13. No. 1. P. 1801.

22. Wang Y., Wan D., Xie S. et al. Synthesis of silver octahedra with controlled sizes and optical properties via seed-mediated growth // ACS nano. 2013. Vol. 7. No. 5. P. 4586-4594. DOI: https://doi.org/10.1021/nn401363e 
23. Bazylyak L. Synthesis of bimetallic nanoparticles $\mathrm{Ag}_{x} \mathrm{Cu}_{y}$ stabilized by polybutylmethacrylate and their use as fillers for electroconductive compositions // Visnyk Lviv Univ. Ser. Chem. 2016. Vol. 57. Pt. 2. P. 440-450 (in Ukrainian).

24. Opeida I. A., Kytsya A. R., Bazylyak L. I., Pobigun O. I. Silver nanoparticle catalysis of the liquid-phase radical chain oxidation of cumene by molecular oxygen // Theor. Exp. Chem. 2016. Vol. 52. No. 6. P. 1-6. DOI: https://doi.org/10.1007/s11237-017-9492-z

25. Kytsya A., Bazylyak L., Hrynda Y., Medvedevdkikh Y. The Kinetic Rate Law for the Autocatalytic Growth of Citrate-Stabilized Silver Nanoparticles // Int. J. Chem. Kin. 2015. Vol. 47 (6). P. 351-360. DOI: https://doi.org/10.1002/kin.20913

26. Kytsya A. R., Reshetnyak O. V., Bazylyak L. I., Hrynda Yu. M. Extinction spectra of aqueous sols of silver nanoparticles as characteristics of their size and size distribution // J. Nano-Electron Phys. 2013. Vol. 5. No. 4. P. 04064 (4 pp.). (in Ukrainian).

27. Ozkar S., Finke R. G. Palladium(0) Nanoparticle Formation, Stabilization, and Mechanistic Studies: $\mathrm{Pd}(\mathrm{acac})_{2}$ as a Preferred Precursor, $\left[\mathrm{Bu}_{4} \mathrm{~N}_{2} \mathrm{HPO}_{4}\right.$ Stabilizer, plus the Stoichiometry, Kinetics, and Minimal, Four-Step Mechanism of the Palladium Nanoparticle Formation and Subsequent Agglomeration Reactions // Langmuir. 2016. Vol. 32. No. 15. P. 3699-3716. DOI: https://doi.org/10.1021/acs.langmuir.6b00013

\title{
CONTROLLED SYNTHESIS OF SILVER NANOPOWDERS
}

\author{
L. Bazylyak \\ Department of Physical Chemistry of Fossil Fuels of the Institute of Physical Organic \\ Chemistry and Coal Chemistry named after L. M. Lytvynenko of the NAS of Ukraine, \\ $3^{a}$ Naukova Str., Lviv, 79060 Ukraine \\ e-mail: Bazyljak.L.I@nas.gov.ua
}

The stepwise reduction of $\mathrm{Ag}^{+}$ions by hydrazine in the presence of silver nucleation centres without stabilizers has been investigated with the use of the spectroscopy method in the UV-visible range. The values of the average diameter and polidispersity of the obtained silver nanoparticles were determined at each stage of the process at the maxima of the surface plasmon resonance absorption bands as well as using scanning electron microscopy. It has been established that such values are in good agreement with the theoretical expectations, which means that in the reaction medium the heterogeneous autocatalytic growth of seeds and formed silver nanoparticles prevails over the homogeneous nucleation process. This fact testifies to the high predictability of the investigated method of obtaining silver nanopowders, the yield of which under the studied conditions exceeds $85 \%$. With the use of spectroscopy and scanning electron microscopy, it was found that the obtained nanopowders of silver well redisperse in water, and the average diameters of silver nanoparticles calculated with the use of the Gaussian and Lognormal distribution functions in the initial sol and after the redispersion of the precipitated and dried in the air at $90{ }^{\circ} \mathrm{C}$ nanopowder of silver in water are close and are within the experimental error. At the same time, in case of one-time addition of $\mathrm{AgNO}_{3}$ solution to the reaction mixture (sol of silver seeds + hydrazine), a polydisperse powder with a particle size of $0,1-2 \mu$ is formed. It is likely that the large size and polydispersity of silver particles obtained with the one-time addition of $\mathrm{AgNO}_{3}$ solution to the sol of silver seeds is caused by 
Л. Базиляк

ISSN 2078-5615. Вісник Львівського університету. Серія хімічна. 2018. Випуск 59. Ч. 2

uncontrolled processes of homogeneous nucleation, autocatalytic growth, aggregation of silver nanoparticles and secondary growth of formed aggregates due to extremely high concentrations of initial reagents. That is why gradual reduction of $\mathrm{Ag}^{+}$ions by hydrazine in the presence of silver seeds of nucleation is a promising, simple and inexpensive method for the production of redispersible nanopowders of silver with a predicted particle size, even in the absence of surface-active substances.

Keywords: nanopowders, silver, seeds, heterogeneous nucleation, surface plasmon resonance.

Стаття надійшла до редколегії 1.11 .2017

Прийнята до друку 11.04.2018 